足利織物業の工場制機械工業化の変遷とその影響に関する一考察*

\title{
Historical Study on the Change to Manufacture of the Textile Industry in Ashikaga and its Consequence
}

\author{
福島二朗 **・為国孝敏***・中川三朗**** \\ By Jiro FUKUSHIMA, Takatoshi TAMEKUNI and Saburo NAKAGAWA
}

\begin{abstract}
This paper deals with the change to manufacture of the textile industry in Ashikaga and its consequence. The general public of the textile industry area knows Ashikaga area in the north Kanto districts from the earliest times.

When Meiji era come, textile industry in this area had introduced by Western countries the system of manufacture. Consequently, this area happened to relationship between the textile industry and the city infrastructure. The effect of this study, we cleared about their relation to a selection of Tobu railways route and a land-use planning in Ashikaga City.
\end{abstract}

1 はじわに

わが国の多くの地方都市では、近世以来の伝統的な産 業を基盤として都市経済が形成されてきた。地方都南に おけるこのような在来産業は、明治維新を契機として大 きく変革する。それは、明治政府による封建国家から近 代資本主義国家への急速な脱却のため推し進められた殖 産置業政策が大きく関かっており、インフラ整備や欧米 の先進技術・機械設借の導入移植など、明治政府の強力 な指導によって、工場制機械工業化が進展したものと考 えられる。

疗木県足利市は、東京加北方約 $80 \mathrm{~km}$ の北関東地域 に位置し、近世以降、交易による江戸との結びつきによ り、織物業を基盤上して地域経済が形成された。乙の徭 織物菜㤌、織元・儥機経営、家内工業老経て、大正後期 から昭和初期にかけて工場制機械工業化が進展した。こ のような足利市における工場制機械工業化の進展の背景 には、明治政府による微業政策が大きく関わっているむ の上思かれるが、特に、明治 35 年の政策による模範工 場（足利模範撚系合資会社）の設立がその端緒であった 上考えられる。

従来、足利市にお打万織物業の展開・進展過程につい ては多くの研究成果が報告されている。しかしながら、 これらの研究の多くは、辅物経営の形態・生産楧造问関 するもの、さらに生﨎工程および技術の進展に関吉る研 究であり、織物業とインフラ整借・都节形成との関わり

\footnotetext{
*Keywords: 足利織物業、工場制機械工業化、影響分析

**正会員 足利工業大学工学部土木工学科雎師 于326-8558 足利侍大前町 268-1 TEL 0284 (62) 0605 FAX 0284 (64) 1061

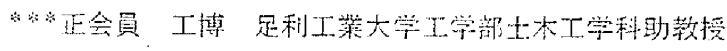
必的正会員工博 足利工業大学工学部土木工学科教授
}

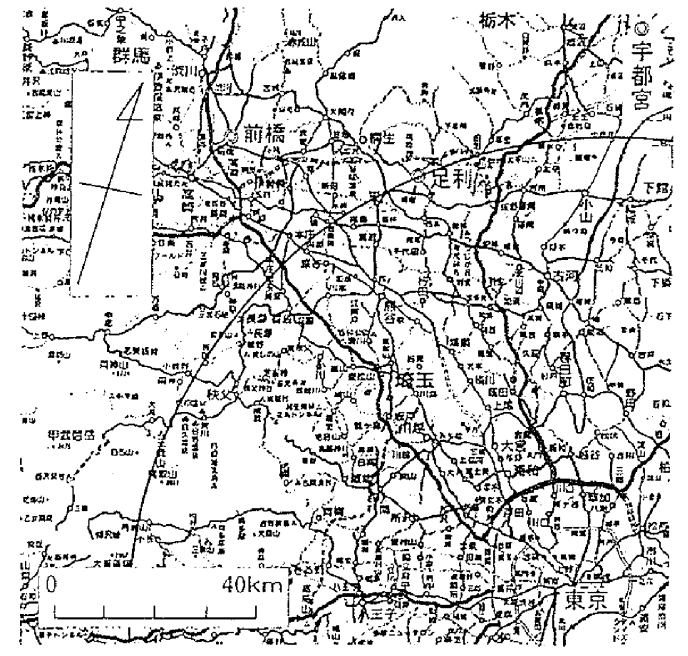

図 -1 対象地域

については充分な検証が成されているとは言えない。 そこで本研究では、足利市を事例として、織物業の機 械制工場化の進屡要因とこの変僄老分析与る中で、官民

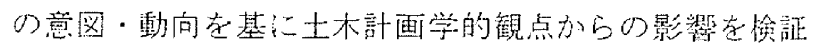
寸ることを目的とする。

具体的には、鉄道駅の設置 (賁武鉄道) と旧都市計面 法の適用に上万用途地域の設定に至る過程について、緎 物莱の工場制機械工菜化の検証女通して考察を行うこ上 上小打。

図-1に対象地域艺示卞。

\section{2 本研究の意義}

本研究は、足利南を対象として、織物業の機械制工場

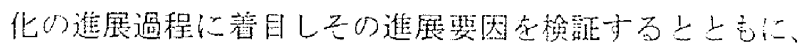

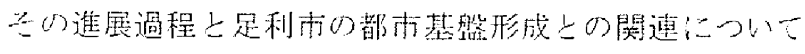
梌証䘮行うこ上を目的としている。

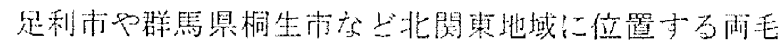


機業圈は、古くから京都书上び江戸上の交易によっ下織 物業が成立していた。特に足利市は、明治政府が推進し た近代化政策の中で織物業の近代化が大きく進展し、わ が国有数の織物産地として発展した地域である。そのた め、従来、わが国の織物業の展開および発展過程に関す る研究の中で、足利市が事例または関連資料として数多 く取り上げられている1)。従来、この種の研究の多くは、 経済史学の分野が先行して行われている。

一方、足利地域に限定した織物業に関方石研究は、1900 年代初頭に荒川宗四郎により行われている2)。荒川は、 足利織物の起源からはじまりその展開過程孝詳述す万中 で、特に近世以降に㧍性る生産および流通形態について 整理している。その後、経済史学の分野からのアプロー チが行われ、1960 年に入交好脩·工藤恭吉・市川孝正ら早 稲田大学経済史学会により『足利織物史』が編箱され ${ }^{31}$ 、 織物経営の形態および生産構造や技術の進展状況、さら に組合組織の変遷・関わり等、足利織物全般にわたり集 大成された。また、1977年の市史編築過程で地方産業史 として取り上げられるとともに4、1980 年代以降には、 市史編筇に携わった日下部高明により、産業地理学の分 野からのアプローチによる地域の生産構造の変化に関す る検証等が行われている5)。之の後、川村晃正は一織物 業者の詳細な史料の検証を基に、明治期にお性る織物経 営の実態解明を試みている6)。

このように、足利地城の織物業に関する研究は、経済 史学・産業地理学分野からのアプローチにより多くの蓄 積が成されている。しかしながら、これらの研究蓄積は 産業史としての成果であり、インフラ整備および士地利 用といった土木䛿学的観点からの检証は行われていな W。

本研究は、織物業の工場制機械工業化への進展要因の 分析上いう産業史の一部分についての検証は行うものの、 その過程の中で、インフラ整備および土地利用計画策定 八の影響分析という言利ば土木計画学的なアプローチに 上る検証を試みるものであり、ここが本研究の意義とす るところである。

\section{3 足利地域上織物策の成立}

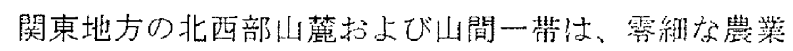

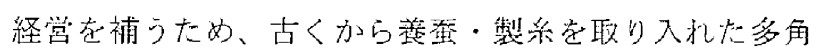
的㕮業経営が行われていたう。

『上州山田郡桐生頱 54 分村、並隣国野州足利辽者、都 而山問之谷々にて、田畑少く、其上砂にて羋業不利之場 所故、百姓渡址難儀に付、往古上り銘々農業之暇、虫飼 いたし、または紙を潉、絹を緎、作業仕来り』

「機屋共始末畫付（天保 7 年) 1 (1)

と示されるように、足利周辺では、耕地狃险のため古く から織物業が営まれていた。
足利の織物は、『東大寺要録』注1)や『徒然草』洼りに もその名が記されているが、それが商品として党贒され るようになるの注 1648 (佂保 3) 年に開設された桐生の 織物市を通じてである。その後、1738（元文 3）年に京 都西陣から、㮸来の「居坐機」に代わる「高機」が桐生 に移入され、天明期（1781〜1788 年）以降には足利に も普及した。足利で生産された織物は、各種の縮緛・䍃 織・琥珀等の絹織物、秽織・小倉織等の綿織物、さらに 絹綿交織物も開発された。1832（天保3）年に注足利独 自の織物市が成立寸るとともに、しだいに原料采は自家 生産加占外部購入に代わり、生産・販売形態毛社会的分 莱が行われた。

このように、足利織物の名声は、江戸期に確立した上 言えるが、この背景には、江戸市場における需要り增大 とともに、江戸市場への輸送路として 1624 (寛永元) 年 に開設された ${ }^{8)}$ 渡良瀬川舟運が大きな役制安果たしたと 考えられる。特に、足利に織物市が開設されてからは、 市で売貿された織物は市（月六回開催される六斎市）の 翌日には渡良瀨川舟運の最終遡行河岸であった北猿田河 岸（現足利市猿田町）加“六斎早舟”之呼将れた舟に 積載され、渡良瀨川・利根川・江戸川を経由して江戸人 と出荷された。当時、足利から江戸までは 37 里、2 日 の行程であった ${ }^{9 !}$ 。

図-2に足利一江戸間の航路を示す。

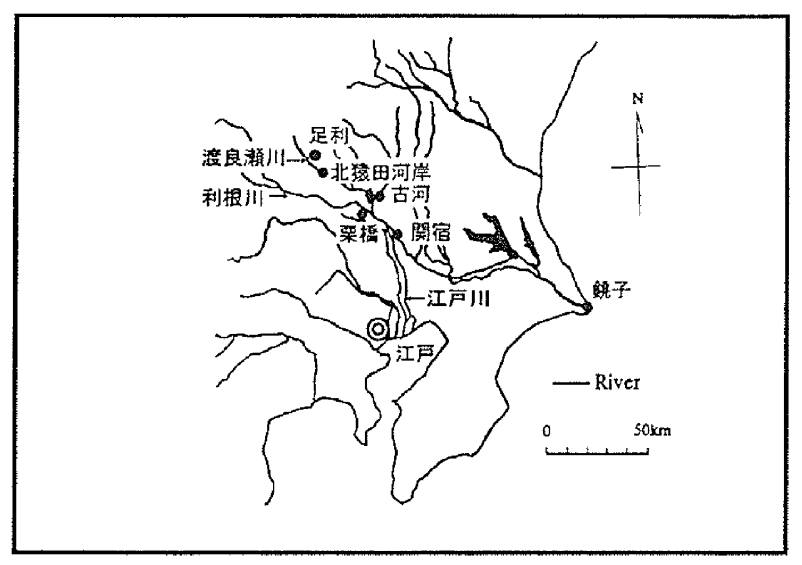

図-2 足利一江留間の航路（著者作成）

4 殖産與莱政策による足利織物莱の動问

（1）明治政附による近代産業育成政策

明治政府の近代化政策结、富国強兵・殖産興蔝基朝

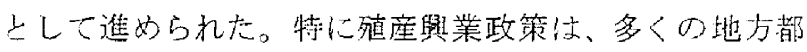

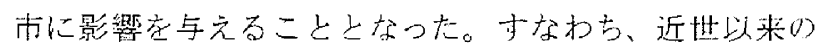
石高制と呼代れる米在中心とした経珮体制から、産業革 命以降の欧米諸国で台頭した資本主義的生産様式による 経済体制八上、移行が四られたのである。

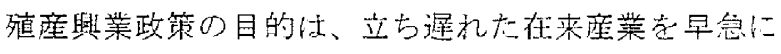
資本主義的に肓成することであり、そのため先進欧米諧

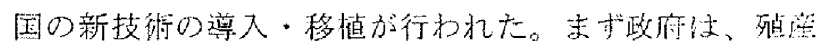




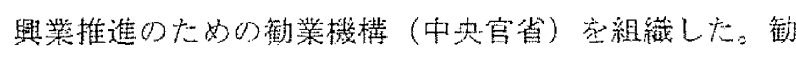
業部門の管罌は、1870（明治３）年心新設された工部省 が担い、その後、1873(明治6) 年以設置された内狢省、 さらに 1881 (明治 14）年に設犆された農商務省へと引 き継がれだ01。

殖産與業政策において、当初政府が最も力を注いだの は輸出增進・翰入防遏のための應業の弆成で直り、瀻維 産業の中でも特に紡績・製杀業が政府の保護・育成の対 象之なった。之のため、官営模範工場の設立や欧米の最 新機械の貸与等、多額の国家資本が投下された。製采部 門では 1870 (明治 3) 年に富网製糸場が、また、紡績部 門では堺紡績所・広島綃績所・愛知紡續所等が 1872 (明 治 5) 年加 1881 (明治 14) 年に加けて官営工場とし て設立されるとともに注3、さらにいくつが民営工場も 設立された ${ }^{11}$ 。聿た政府は、殖産興策政策実現のための 一手段として、「鹳業博覧会」おおよ゙「共進会」炎各地で 開催した。これは、全国各地から代表的な物産や機械・ 新技術等屡示し、歷業技衔の向上を図るとともに、製 品の品質索向上し外国留易の振興索促進すること老目的 としていた。第1回内国勧業博覧会は1877（明治 10） 年に上野で開かれ、ガラ紡（和辦器）やジャカード等が 出品され、るの俊各地で開催された。

一方、明治前期において紡績業は政府の保護・育成政

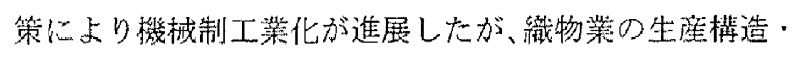
形態に大きな進展はなかった。しかし、明治 10 年代後 半以降の絹織物の輸出增大に伴い、その霞要に対応して 洋式織機ジャカードおよびバッタンが急速に揞及してい った。こうした技街的改善に伴い、織物会社も备地に設 立された。䋚織物壮をの㣪、明治 20 年代加ら 30 年代に かけて重要輸出品となり、政府の保護・育成の対象とな った。

織物輸出が伸長するに伴い粗製濫造など品質低下が問

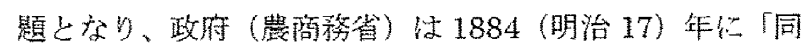
業組合準則」（㖘商務省存達第 36 号）高会し下之の防 止染図った。この「同業組合準則」は、製品の品質向上・

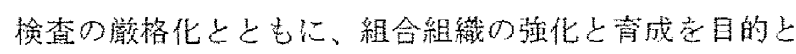
したものであり、告の後、1897（明治 $30 ）$ 年の「莗要翰 出品同業組合法」(躃商務省法令第 47 号)、さらに 1900

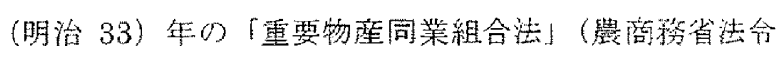
第 35 号) へと引さ継がれた。また、1902（明治 35）年

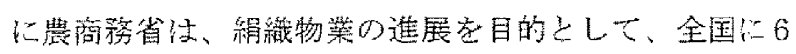
ケ所の模範工堭設立を決め、設立に際して金 10 万円 もって最新機械を購入し貸与している。さらに、この時

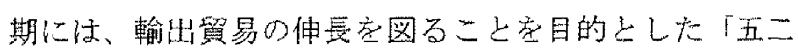
会」が組織され、各地で「五二共進会」を開催する一方、 製品の品質向上を促し、輸出貿易の伸長に大きく䨒与し

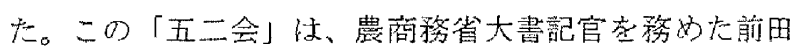
正名が主唱し組織化され、外貨獲得のための有力な输出 品である織物・陶器・整器・製紙・銅器の五品心、のち に花筵・唃刻の二品意加えた輸出振與のための商工業者 による全国組織であったい。

このように、明治前期に括いては紡績・製禾菜が、さ らに明治後期には輸出䋧織物字中心とした織物業の機械 制工策化が大きく進展した。その背景に性、官営工塌书 よび模範工場の設立、国家資本の投下による最新機械の 導入・移植、組合組織の强化と育成、さらに博䁈会・共 進会の開催等、政府による積極的な陈業育成政策が大き く影㗽しているものと考えられる。

\section{（2）足利地域求よび足利織物業の動问}

明治政付に上る㕍業育成政策の推進に上り、足利地域 および足利織物業は大きな影響学受けた。乙れは、洋式 織機の導入や同業組合の組織化という形で結実し、工場 制機械工業化進展のための環境整備が促進されたと考え られる。ここでは、足利織物業における機械制工業化が 現え始めた明治 30 年代から、工場制機械工業化が大き く進眼した大正末期までを対象として、足利地域贴よび 足利織物業の動问について検証莸行う。

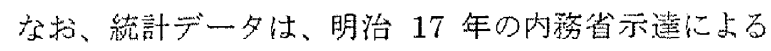

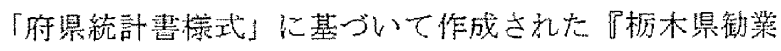

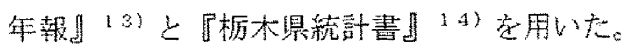

a) 織戸数㧍よび洋式織機の導入とその後の動態

明治政府に上る库粟育成政策の推僬に上り、足利織物 㧘は大さな影制索受けた。明治前期において、紡績・製 系業の機械制工業化は政府の活い保護・育成に上り大き く進展したが、織物業は大きな進展はなかった。しかし

表 -1 織戸数执よび織機数の推移

\begin{tabular}{|c|c|c|c|c|c|c|c|}
\hline \multirow{3}{*}{ 年 代 } & \multicolumn{4}{|c|}{ 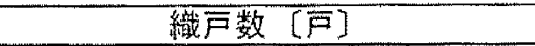 } & \multicolumn{3}{|c|}{ 機数 [臺] } \\
\hline & \multicolumn{3}{|c|}{ 独立棠業 } & \multirow{2}{*}{ 霓機業 } & \multicolumn{2}{|c|}{ 器械機 } & \multirow{2}{*}{ 手織機 } \\
\hline & 工埸 & 家内工楸 & 織元 & & 廣幅 & 小躯 & \\
\hline 明治33年 & \multicolumn{4}{|c|}{619} & \multicolumn{2}{|c|}{56} & 19293 \\
\hline 明治36年 & \multicolumn{3}{|c|}{1051} & 6950 & \multicolumn{2}{|c|}{342} & 17997 \\
\hline 明治38年 & 33 & 78 & 541 & 8533 & \multicolumn{2}{|c|}{67} & 21830 \\
\hline 明治44年 & 45 & 146 & 718 & 7411 & \multicolumn{2}{|c|}{92} & 10011 \\
\hline 大正2年 & 38 & 112 & 712 & 7326 & \multicolumn{2}{|c|}{80} & 10059 \\
\hline 大正6年 & 41 & 127 & 304 & 7226 & \multicolumn{2}{|c|}{322} & 10586 \\
\hline 大正15年 & \multicolumn{4}{|c|}{3880} & \multicolumn{2}{|c|}{3504} & 4251 \\
\hline
\end{tabular}

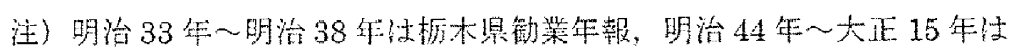
杤楾統計量基心作成 
ながら、洋式織機の移植・遒入によりその生謶量は增大 した。

表一 1 に、1900（明治 33）年加ら 1927 （大正 15）年 における足利郡内（足利町索中心に1町 15 村で構成。 大正 10 年からは足利町の市制施行に伴い1市 15 村）の 緎戸数（織物業に従事する戸数）、および力織機・手織機 数の動態を示す。織戸数の推移で法、明治 36 年から大 正 6 年までは工場・家内工業・織元・賃機業上に分類さ れて集計されているが、その前後についてはこれらの総 数として集計がなされている。分類基準の噯昧さにより、 個々の分類における系統的な䖯勢の把握はできないが、 総数上しては明治 38 年の 9185 戸をピークとしている。

また、洋式織機ジャカード（紋織り装置機）とバッタ ン（飛杼装置機）はともに手織機でありながら、従来の 居坐機や高機に比べかなり生産能力が高かった。足利に おける洋式織機の導入は、川息長十郎らが 1877 (明治 10) 年の第 1 回内国衔業博覧会に出品されたジャカード 1 台 を購入したのがその始まりである。表一 1 に示与手織機 の中にジャカードおよびバッタンが含まれているが、個々 の分類は無く、その数量は不明である。そのため、両織 機のその後の普及状況仕不明であるが、1900（明治 33） 知の調盉では、ジャカード 1944 台およびバッタン 128 台と放吉。このことから、明治 10 年代以降、ジャカ ードおよびバッタン专徐々に普及していったもの上考え られるが、その詳細な普及過程については今後の調查が 必要である。

また、力織機は、1900（明治 33）年に植木宗平工場に 豊田式織機が導入され、翌 1901 （明治 34）年には木村 浅七工場に部分的では品るが力織機が据えられ、その後、 1911 (明治 44）年にスイス製のルーチー力織機 46 台が

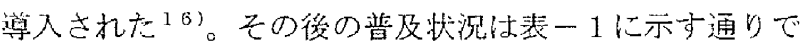
あり、大正末年には大きな技街的革新が行われたもの上 涜えら扎右。

b) 組合組織の强化とその動向

足利では、明治 10 年代後半から明治 30 年代前半にか 汁て「機業改善」上呼ばれる技術革新を中心とした社会 改良運動が地域をあげて行われたいてこの「機業改善」 の背景には、明治 10 年代後半の松方デフレによる不況 Ł之もに、染色の粗雑や尺足らず等の粗製濫造によって 足利䋨物の信用が失壁し、---時停滞学余儀なくされたこ とがあげられる。明治政府に上る組合組織の強化策は、 この上うな製品の粗製濫造に対寸る防護とその品質向上 它目的上していた。政府经上る組合組織の强化・育成策 の発令を受けて、足利地域の織物關連業者らは、先の強 化に取り組んだ。

1882（明治 15）年に足利で住、織物㮍者の組合として 估じかて足利工商会が設立された。その後、1884（明治

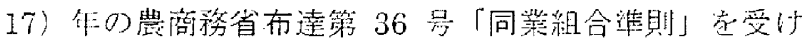
下、新たに特別商標組合定設琶して織物製品の取り蟐ま

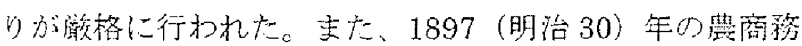

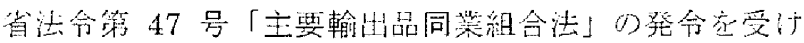

て、足利工商会から改組していた足利機栄会に代かって、 1899（明治 32）年に足利織物同業組合を組織し、組合組 織の強化が図られた ${ }^{18)}$ 。また、この間、1885（明治 18） 年に近代的織物技術に関寸る教育機関として織物講猊所 が設立され、さらに織物検查所・織物試験所が設置され たが、これら機関の設置は組合主導により行われた。

この上うに、足利地域の織物業は、政拊の施策によっ て組合組織が強化・育成されるとともに、組合主尊によ る製品の品質管理とその向上が図られることになった。

c）模範工場の設立上機械制工業の進展過程

明治 20 年代から 30 年代にかけて、絹織物は外貨獲得 に最も有効な製品としてわが国の重要翰出品となった。 この閒足利では、岩本良介・長谷川作七·秋間為八・本 村浅七らの有力者により輸出用の絹織物生産が始められ るとともに、1885（明治 18）年に渡米した堀越善重郎を 通じて米国メーソン商会との直輸入が行わ礼るなど19)、 足利産絹織物の海外市場への参入が行われている。この ような状況の中、1902（明治 35）年に政拊（農商務省） は、輸出絹織物の保護・育成老目的として、全国に6ヶ 所の模範工場の指定・設立決めた。その内容は、金 10 万円の国家凟本を投入し、最新の機械索購入しこれを貸 与するというもので、桐生・足利 ·米沢 - 福井 · 京都西 漣・富山がその対象となっだの。対象地6ヶ所の条件は、

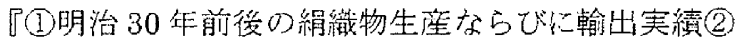
生産にあたっての産地の体制、(3)明治 34 年の重要「翰 出品同業組合法」にもとづく組合組織の存在、(4)産地 のイノベータとしての指䆃力ある人材の存在とその実 際的活動』 (2)

等で京つた。

翌 1903（明治 36）年3月 26 日に足利模範撚系合瓷会 社が設立された（図一 3 参照）。会社所在地佂、足利郡山 辺村大字田中字内山であり、現在の東武鉄道足利市駅の 西隣であった。社長に注、木村浅七・秋間為八ら有力機 業家 7 名による取締役の選挙により木村浅七が就任し、 監查役は足利銀行頭取の荻野万太郎ら5名であった 21。

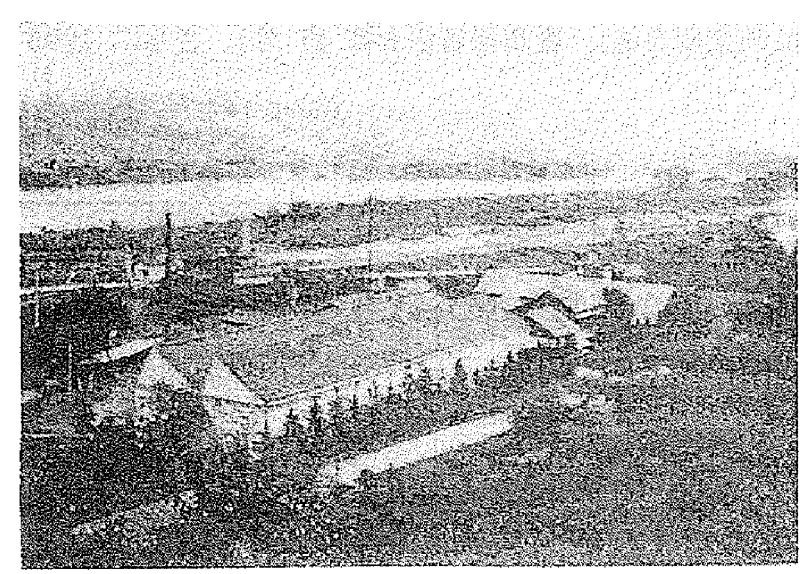

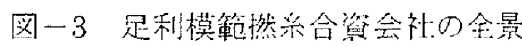

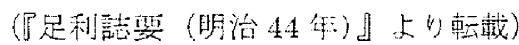


また、米国アトウードモリソン会社製撚系機戟 30 台が 農商務省から貸与されるとともに、会社資本に上り同会 社製然系機械 18 台が購入され、操業が開始された。ま た、この足利模籁撚采合筫会社の設立後、1908 (明治 41) 年には両毛製織合資会社も設立されている。

このように足利地域では、模範工場の設立を契機とし て、綟織物生産の主要工程が機械化されるとともに、前 揭表一1に示すように工場および織機の普及など、そ の機械制工業化が大きく進展したもの上考えられる。

d) 鉄道の誘致

足利地域の織物の輸送は、近世以来そのほ上んよ゙が渡 良瀬川舟運によって行われていたが（前揭、図一2参照）、 このような前近代的な輸送形態ではもはや応じきれない 輸送要請が出現した。そのため、舟運に代わるさらに充 実した輸送路の整備が必要となり、増大する輸送を賄う には鉄道の敷設が最も効果的と考えられた。また、日本 鉄道会社による好調な営業成績は、機業家の鉄道に対す る関心をさらに高めた 22)。1883（明治 16）年に日本鉄 道会社の第二区線計画立案に際し、足利の有志は熊谷. 足利・栃木・宇都宫通過案穵推し株金募集が行方えた。 その中心となったのは、当時の足利を代表する機業家達 であった。しかし、この案は陸軍の反対により結局見送 られた朔4!。その後、鉄道建設運動の中心であった木村半 兵衛 (四些) - 岩下善七郎·戸叶角蔵・大山岩次郎ら織物 賢継商の努力によって、雨毛鉄道案は大きく前進した。 鉄道技官官僚として著名な渡辺洪基（東京大学が改組さ れた帝国大学初代総長)に上り测量お上び収支予算調查 が行われ、その具体計画が作成され、「上野下野東京間と 鉄道を連絡し其物産運搬の便在起寸（定款草案）」という 産篓鉄道上して、1886（明治 19）年 11 月に耐毛鉄道株 式会社創立願書が杤木・群馬両県知事に出され、闹年 12 月に内務大臣に進達された。翌 1887 (明治 20）年3月 に両毛鉄道株式会社は発足し、1888（明治 21）年5月、 两毛鉄道第一区線のうち小山一足利間が開通した23)。こ れにより、日本鉄道（小山）学経由して首都東京と連結 した。

その後、絹織物が重要輸出品上して政附の保護・育成 の対象となったことから、絹織物扔よび生米の主裂座地 である両毛機業地上東京を直結寸る鉄道教設案が出され た。1895（明治 28）年4月、帝国商業銀行会長原六郎. 総武鉄道社長本間英一郎・東京海上火災保隃会長兼山陽 鉄道取締役末延道成・第四○銀行（館林）頭取南条新六 郎・目崎銀行頭取川崎八右衛門・帝国大学（現東京大学） 総長渡辺洪基ら 12 名の発起人により、「查武鉄道株式会

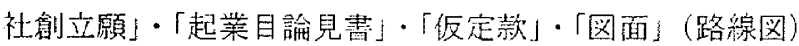

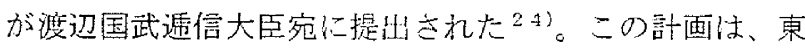

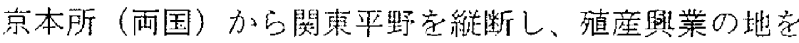
結び足利に至るという計画て、、日本鉄道第二区線上洞毛 鉄道に接続し、相互利価空図るこ上等目的上していた。

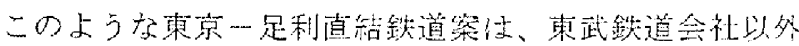
にもいくつかの鉄道会社から計画案が出され下いた。
礼らの中から東武鉄道会社上毛武鉄道会社仁作許状が 下りたが、毛武鉄道は結局できず、1897（明治 30）年 9 月に東武鉄道株式会社に本免許状が下り、翌 1898 (明治 31）年 11 月に工事に着手した。その後、1899（明治 32） 年 8 月に北千住一久喜間が開通し、1902（明治 35）年 9 月に注加須まで延長され、翌 1903 （明治 36）年4月に 注川俣まで延長され利根川に到着した。るの後、利根川 の架橋問題・日露戦争などにより川俣一足利間の工曹は 一時停滞した。しかし、1905（明治 38）年の日露戦争終 結之、同年 5 月の根津嘉一郎の尃務取締役就任（同年 11 月に初代社長就任）に上り、川俣一足利間の本免阡状が あらた如て下れ、利根川架橋の徭、1907（明治 40）年 8月に開通した2ら)。1896（明治 29）年に仮免許状が下 りてから 11 年要した開通であったが、足利町駅は、当 初の計画とは異なり、両毛線との接続はなく、渡良瀬川 の対岸 (右岸) に設置された。この東武鉄道足利町駅の 位置決定については、次章で検証したい。

図-4に、両毛鉄道と東武鉄道の位置を示す。

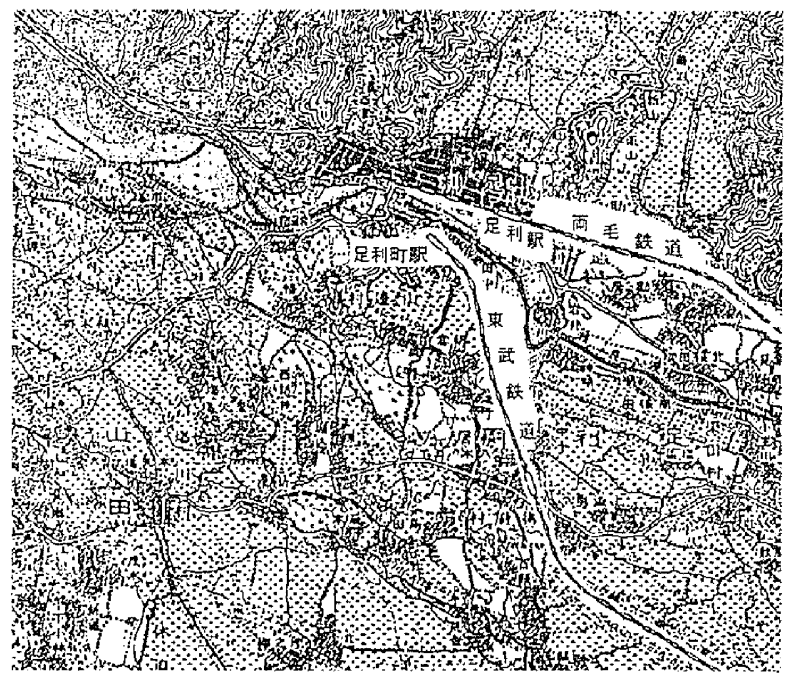

図-4 明治 40 年開通の東武鉄道 (『大日本帝国陸地測量部（明治 40 年測図)』に 簕者加筆)

5 工場制機械工業化の進展に上る都市基盤形成への影 響分析

ここでは、前章までの足利地域における工場制機械工 業化の僬展過程を踏まえ、それが都市基盤形成によ゙のよ

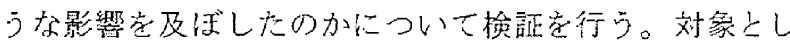
た年代仿、東武鉄道敖設計函案引゙具体化した明治 30 年 代前半から、足利市が旧都市計画法の適用受的学用途 地域が設定された昭和 9 年までとした。また、統計デー 夕如、『栃木県統計書』261在用い、厉木県統計書』で は把握でき孙件代および情媇については、『足利郡統部 彗』2引)使用子名こととした。

\section{（1）東武鉄道足利町駅の位置決定}


a) 計画ルートの変遷

東武鉄道会社による足利一東京直結鉄道敷設案が初め て提出されたのは、1895（明治 28）年 4 月である。当初 の計画では、足利が終着点であり、両毛鉄道足利駅に接 続する計画であった。図一 5 は、1896（明治 29）年4月 の「起業目論兌書仮定款変更願」に添付された計画路線 図である。この計画案では、群馬県館林からほぼ直線で 両毛鉄道足利町駅に接続するルートが採られている。こ の案に対し、足利機業組合では、

(明治 29 年 4 月 23 日)

『真武鉄道足利起点ノ件二付役員会 $习$ 組合事務所二開 リ、来会セシ八本村・長谷川・初谷・市川等ノ四名ニシ テ、起点ノ如何八足利地方二於テ将来得失八商工業上二 大関係アルニヨリ、足利二決定スルコトラ其会議二要求 スルノ議ヨ決定シ退散セリ』

「足利機業組合第一回事務報告」(3)

として、この茶に賛同を示している。

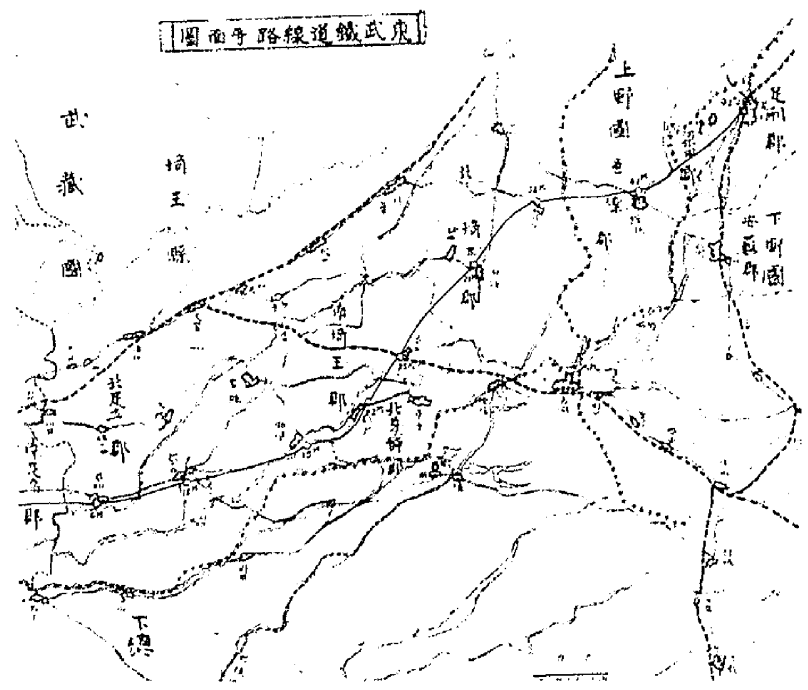

図 -5 明治 29 年申請の計画ルート

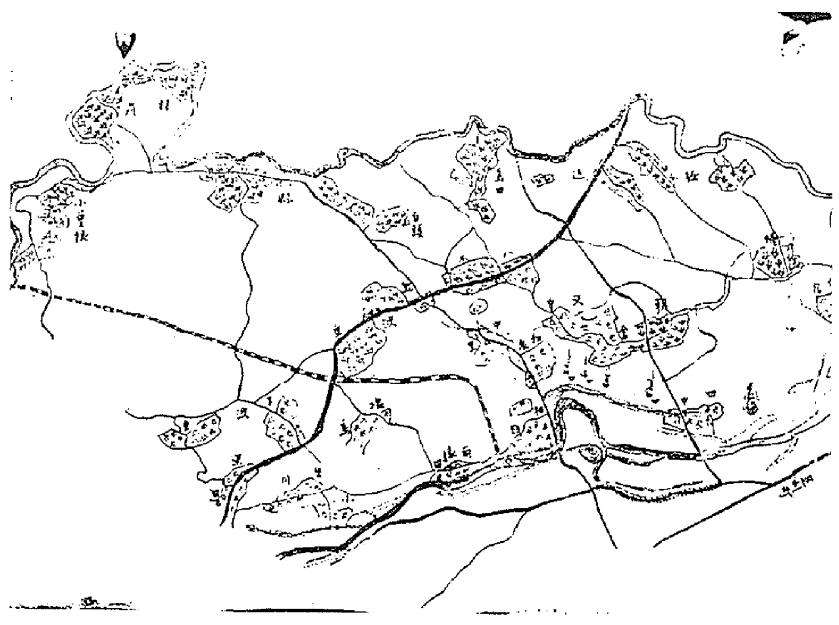

図 -6 御㴻村の請願書に記载のルート (文献 28 加転载)
しかし、このルート案については、現足利市南部の路 線経路の沿線住民から岵路線变更の請願書が数次にわた り提出さ机ている。その内容は、洪水との関的りから渡 良瀬川架橋の際の位置についてである。1896（明治 29） 年 10 月 6 日に御厨村村長秋田善太郎の添書き付きで梁 田村福富の阿部金次郎らにより提出された請覑書には、 路線位置まで記载されている(図一6) 281。このような 状況の中、1897（明治 30）年 5 月に、内務省土木局加ら 渡良瀨川架橋の件につき変更があり、東武鉄道法路線変 更願透信大臣に提出し、同年 9 月に本免許状が下付さ れた。図ー7に、1896（明治 29）年4月および1897（明 治 30）年 7 月に申請（変更）されたルート走方。この 時点では未だ両毛線足利駅接続案であった。

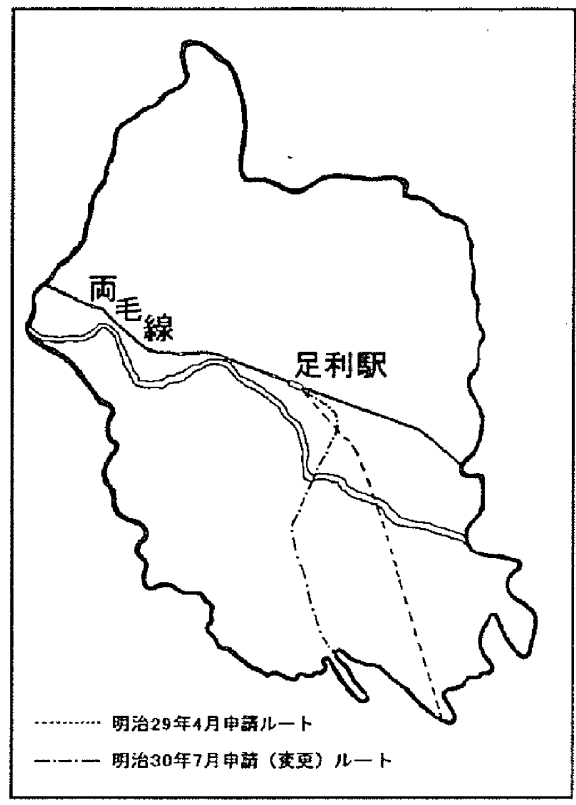

図一7 明治 30 年申請（変更）ルー上図 (文献 24 基に簕者作成)

b ）模籁工場の設立と工場制機械工洋化の進展

模範工場（足利模範然系合資会社）の設立は、1903（明 治 36）年である。二の時点では、東武鉄道は渡良潮川齐 越えて両毛鉄道と接続することで本免許状が下りていた。 輸送の便を考えると、渡良瀨川左岸の耐毛鉄道足利駅周 辺が望ましいと思われるが、前述の通り、渡良瀨川右岸 の山辺村大字出中に設立された。模範工場には、米国製 の最新式撚系機械が配備された。この機械による然系は、 帡来の水車動力による八丁撚系にくらべ然りに吉らがな く、品質の向上（均一化）および性能等、新た好て機械 化の推進が認識された。

この模範工場の設立が契機となり、足利地域における 工場制機械工業化が進虔した。表一2に、1898（明治 31） 年から 1915 (大正 4) 年における足利郡の町村別織戸数 および織機数老示方。図一8は町村の配置を示している。 また、表一 3 に昭和元年から昭和 9 年に拈沙織機台数 规模別織百数老示才。 


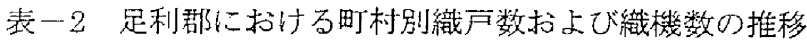

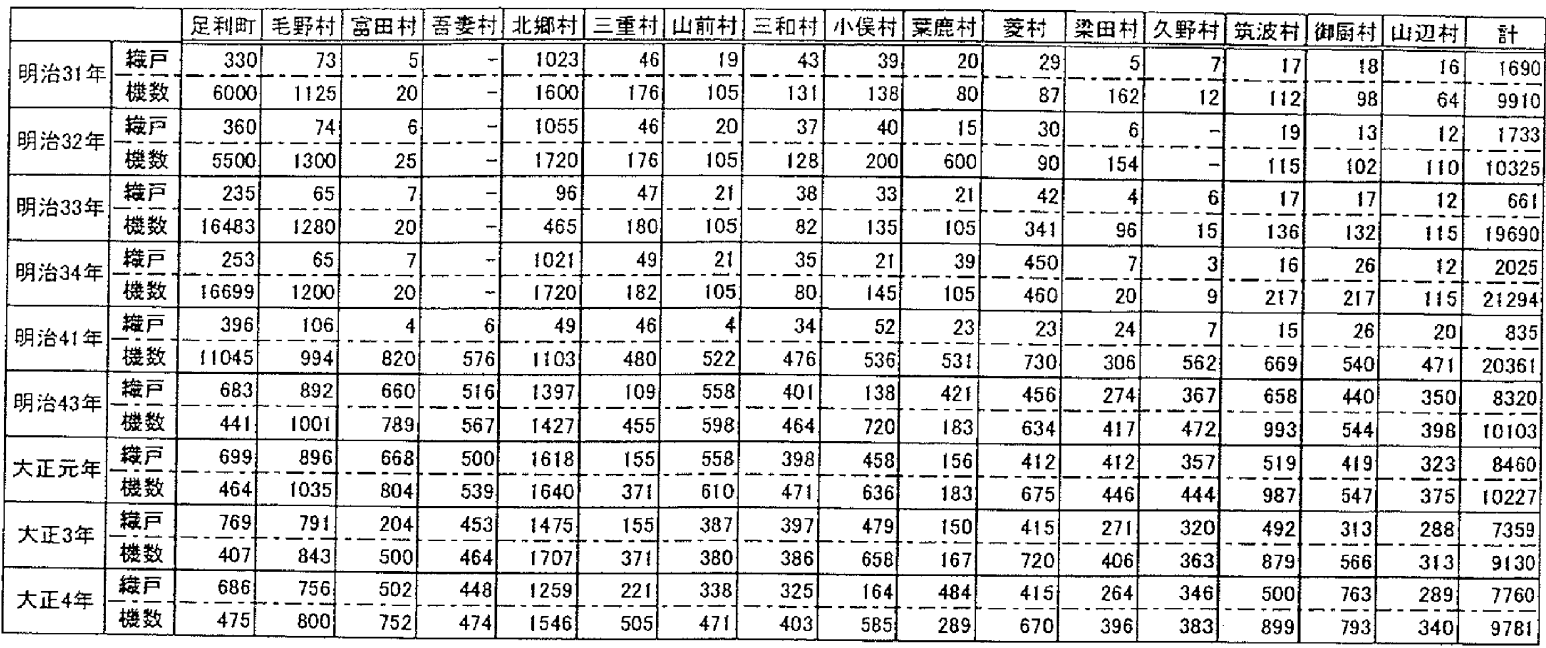

注）足利郡統計書を基に作成

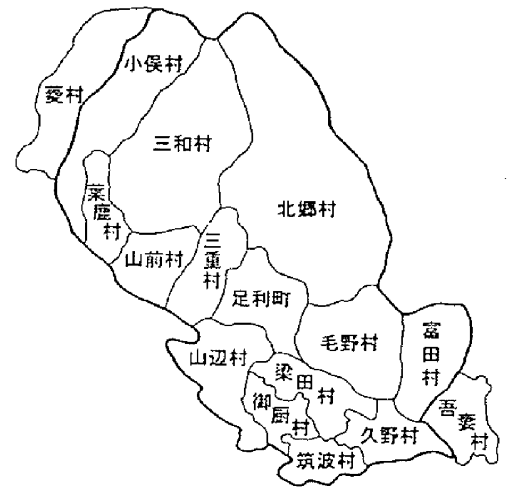

表 -3 織機台数規模別織戸数

\begin{tabular}{|c|c|c|c|c|c|c|c|c|}
\hline & \multicolumn{2}{|c|}{ 10台未満 } & \multicolumn{2}{|c|}{ 10台～50台未満 } & \multicolumn{2}{|c|}{ 50台以上 } & \multicolumn{2}{|c|}{ 計 } \\
\hline & 足利郡 & 足利市 & 足利郡 & 足利市 & 足利郡 & 足利市 & 足利郡 & 足利市 \\
\hline 昭和元年 & 3707 & 81 & 22 & 57 & 5 & 8 & 3734 & 146 \\
\hline 昭和2年 & 3419 & 147 & 38 & 82 & 5 & 12 & 3462 & 241 \\
\hline 昭和3年 & 3557 & 181 & 79 & 125 & 5 & 3 & 3441 & 309 \\
\hline 昭和 4 年 & 2589 & 198 & 116 & 134 & 5 & 4 & 2710 & 336 \\
\hline 昭和 5 年 & 1886 & 234 & 127 & 177 & 5 & 10 & 2019 & 421 \\
\hline 昭和 6 年 & 1949 & 185 & 135 & 158 & 6 & 10 & 2089 & 353 \\
\hline 昭和 7 年 & 1739 & 175 & 188 & 163 & 7 & 9 & 1934 & 347 \\
\hline 昭和8年 & 1360 & 158 & 245 & 134 & 8 & 9 & 1613 & 301 \\
\hline 昭和 9 年 & 1264 & 180 & 275 & 160 & 22 & 9 & 1561 & 349 \\
\hline
\end{tabular}

図一8 足利郡の町村区分図（箻者作成）

表一 2 は、足利郡内における織物製造に関わる戸数の 地区別分布とその動態を示している。戸数および織機数 とも、模範工場の設立以降、郡部に大きく展開していく 過程が確認される。

また表一－3で仕、時代が上がるにつれ、郡部では織機 数 10 台未満の機業家が減少し、10台一50台の機業家が 大幅に增大している。このことは、従来のような市内の 沚元・郡部の農業兼用賃機という生産形態が大きく䎐換 し、郡部においても工場形態およびそれに近い形態が確 立され、形成されてきた方の上考えられる。この時代に おける力織機の普及過程に関する資料は得られなかった が、郡部に扔いては足利銘仙の整織のため力織機が大幅 に導入され普及するとともに、力織機の普及に伴う力織 機の遊休淬が上景した。そして、この余剩生産力の一部 注、当時銘仙の産地として進展していた伊勢崎織物（銘 仙）の製織へと展開した291.301。

c）東武鉄道足利町駅の位置決定についての考察

図一9に、最終決定された東武鉄道足利町駅・計画予 定ルート㧍よび模範工場（足利模範然系合資会社）の位 䈯を示卞。1903（明治 36）年4月に川俣まで延長された 東武鉄道は、川俣一足利間の着工を前に、1905（明治 38） 年4月に廃案となった。その後、翌 1906 （明治 39）年
注）杤本県統計書を基に作成

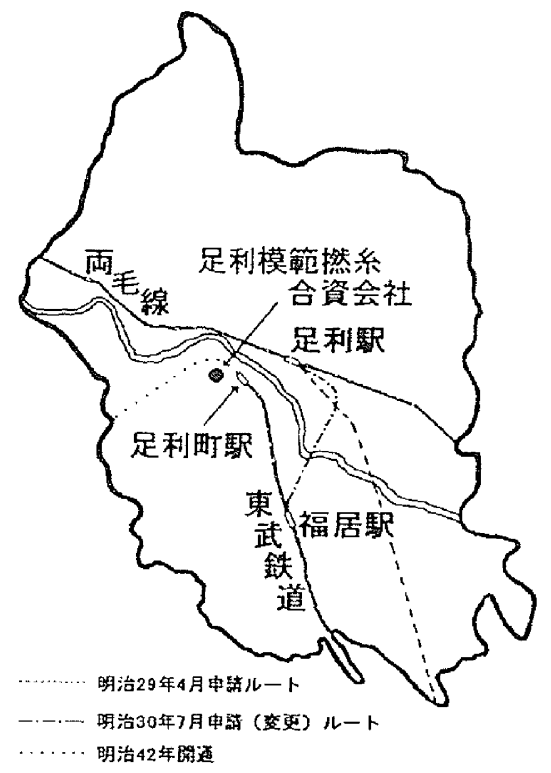

図一-9 明治 39 年に最終決定された東武鉄道足利町駅 (文献 24 学基に䈇者作成)

2 月に再申請され、同年 5 月に再免許ボ下りた。 
しかしながら、この計画案は当初の計画とは異なり、東 武鉄道は渡良瀬川を越えなかった。東武銠道足利町駅は、 渡良瀬川右岸の山辺村大字田中に設置された。足利模範 撚系合資会社の東隣である。この変更案までの経緯につ いては不明であるが、足利町駅の開設において足利の有 力機業家達が支援していることから、この変更案は多く の機業家達の総意であったと考えられる。また、開通式 は、1907（明治 40）年 II月10日に足利模籍撚系合資 会社を会場として行われている ${ }^{31}$ 。

模範工場設立を契機として、足利地域の織物業は工場 制機械工業化が進展し、それは郡部へと展開した。その 後、同じ銘仙製織の地伊勢崎との結びつきが強まり、伊 勢崎は足利と並ぶ銘仙の産地として伸展した。

耐毛鉄道足利駅終着案の廃止と、桐生・伊勢㱦八と伸 長方変更案の背景には、工場制機械工業化進展の方向 を見据えた決断があったものと思われ、その決断には、 織物業の莐術革新・生産形態の転換など、その近代化の 影響が大さく関わっていたものと考えられる。

\section{（2）用途地域の設定}

a）(日都市謤十画法制定の背景321３3

1900 年代以降、凟本主義経済が定着・進展し、それに 伴って、大都市㧍よびその周辺の地力都市への人口・産 業が集中した。政府は、1888（明治 21）年制定の東京市 区改正条例の適用を桩大古る等の対応を行ってきたが時 代に対応した新しい法制度の確立が要請されていた。

このような背景の中、1919（大正 8）年4月に法律第 36 号として、旧都市計画法が公布された。この旧都市計 画法は翌 1920 (大正9) 年1月に施行され、当初は東京・ 大阪・京都・名古屋・横浜・神戸の6大都市がその適用 を受けたが、1923（大正 12）年以降には、檤次適用が拉 大されていった。1933（昭和 8) 年に注改正が行われ、 市町村にも法適用の可能性が広げられた。

また、この旧法と同時に市街地建築物法が制定され（大 正 8年法律第 37 号)、はじめて用途地域の指定が行われ ることとなった。

b）足利市の法適用と用途地域の指定

足利市の市制施行は1921（大正 10）年1月に行われ、 処務規定が定められるとともに、庶務課・人事課・铨業

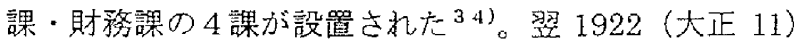
年には都市計画調查委員会が設置されている35)。また、 1927 (昭和 2) 年に旧都市計画法、翌 1928 (昭和 3) 年には市街地建築物法の適用を受け、1929（昭和 4) 年 6 月には足利市・三重村・山辺村拉よび毛野村（一部を除 く） 2417ha が都市計画区域として指定された36)、37)。

その後、1932（昭和 7）年9月に都市計画区域の拡張 が行われ、御欴町・梁田村および北楖村の一部（大字大 月・利保・江川）の 1545 ha が新たに都市計画区域に編 入されだ32、3け)。また、1934（昭和 9）年には用途地 域が指定された40!。

図一10に、本調查により得られた「足利市都市計畫行
政區劃圖」を基に作成した 1929 （昭和 4）年の都市計

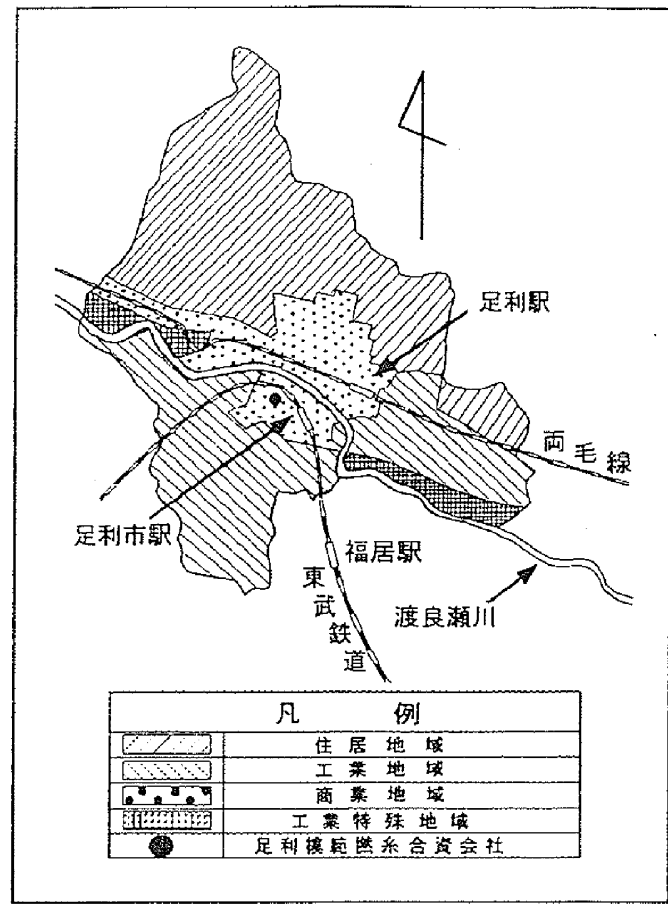

図一-10 昭和 4 年都市計画図 (『足利市都市計鞇行政區劃圖 (足利市所藏)』を基に著 者作成)

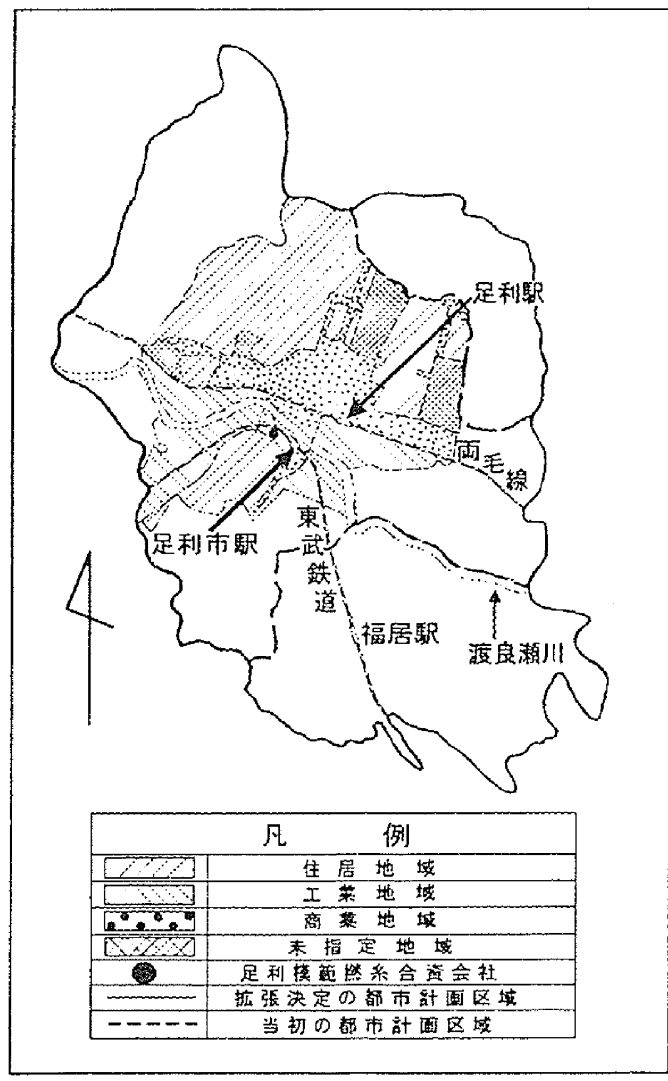

図一11昭和 9 年都市計画図 (足利都市計嚳街路網及地域指定圖 (足利市所蔵)』 岂基红筆者作成） 
画図（用途指定のみ作成。街路恬省略）を、また、困一11 に「足利都市計盖街路網及地域指定圖」を基に作成した 1934 (昭和 9）年の都市計画图（问）を示す。

c）用途地域の設定についての考察

图一100昭和 4 年に招ける都本計画図では、都市計画 区域の 2417ha 全域に用途地域が設定されている。用途 の種類は、住居・工業・商業地域の3 種に区分され、他 に工業特殊地域が定为られている。商業地域は、旧足利 町を中心として両毛線足利駅周辺を会办、また東武鉄道 足利市駅周辺をむ包含している。この渡良瀬川南部（右 岸）の東武鉄道足利市駅周辺の，山辺村大字田中に建てら れた模籁工場（明治 43 年に模籁工場足利撚系株式会社 に移行）も、商業地域に含まれている。また工業地域は、 山㲽村大字田中を除いて、両毛線以南の全域に設定され ている。これは、織物関連工場が郡部一展開していたこ とによるものと思われる。

図一11の昭和 9 年の都市計画図において、大きく变更 している点は、用途地域全体が縮小したこと、および南 部地域の用途変更である。南部地域の模螌工場周辺は、 商業地域加ら工業地域に指定変更が行われている。また、 ほほ南部地域全域だった工業地域は、東武鉄道の沿線周 辺にまとめられ、さらに、山辺村中心部惊居地域に指 定替えされている。これは、貨物翰送（織物）を主力上 した東武鉄道による、足利市駅以南の工場求よび人口集 樌への対応と考えられる（表一 4 および図ー12参照）。

図一10 から図一11 ○の変更は、足利織物業の機械制 工業化の基盤となった模籁工場への期待と、先行する織 物業の動向に対する施政の現れであったと考えられる。

\begin{tabular}{|c|c|c|c|c|c|c|}
\hline 市町村㞋 & 大正1年 & 大正9年 & 大正 14年 & 昭和5年 & 昭和10年 & 指致 \\
\hline 足利郡全体 & 67922 & 69624 & 72236 & 73191 & 81824 & 120 \\
\hline 峛辺 村 & 4252 & 5151 & 8195 & 8487 & 10275 & 242 \\
\hline 崔 & 4257 & 4723 & 5134 & 5038 & 5241 & 123 \\
\hline 3 & 2458 & 2423 & 2346 & 2297 & 2414 & 98 \\
\hline 构 & 3426 & 3161 & 3114 & 2989 & 2912 & 85 \\
\hline 筑波 & 4337 & 4361 & 4225 & 3986 & 3929 & 91 \\
\hline
\end{tabular}

(単位：人)

注 1) 杤木県統計書を基に作成

注2）指数は、大正元年を 100 とした時の昭和 10 年の 指数定示主。

6 定とわ

本研究では、足利市を事例として、織物業の工場制機 械工業化一の進展過程の检証を行うととむに、その進展 に伴う都市基盤形成への影製分析を行った。その結果、 以下のことが明らかになった。

（1）東武鉄道足利市駅の位置決定には、足利地域の織 物業における機械制工業化の進展が大きく影製している。 特に、模範工場の設立上、足利郡部に求ける機械制工業 化の進展が、計画路線の变更に大きな影響を与えた。

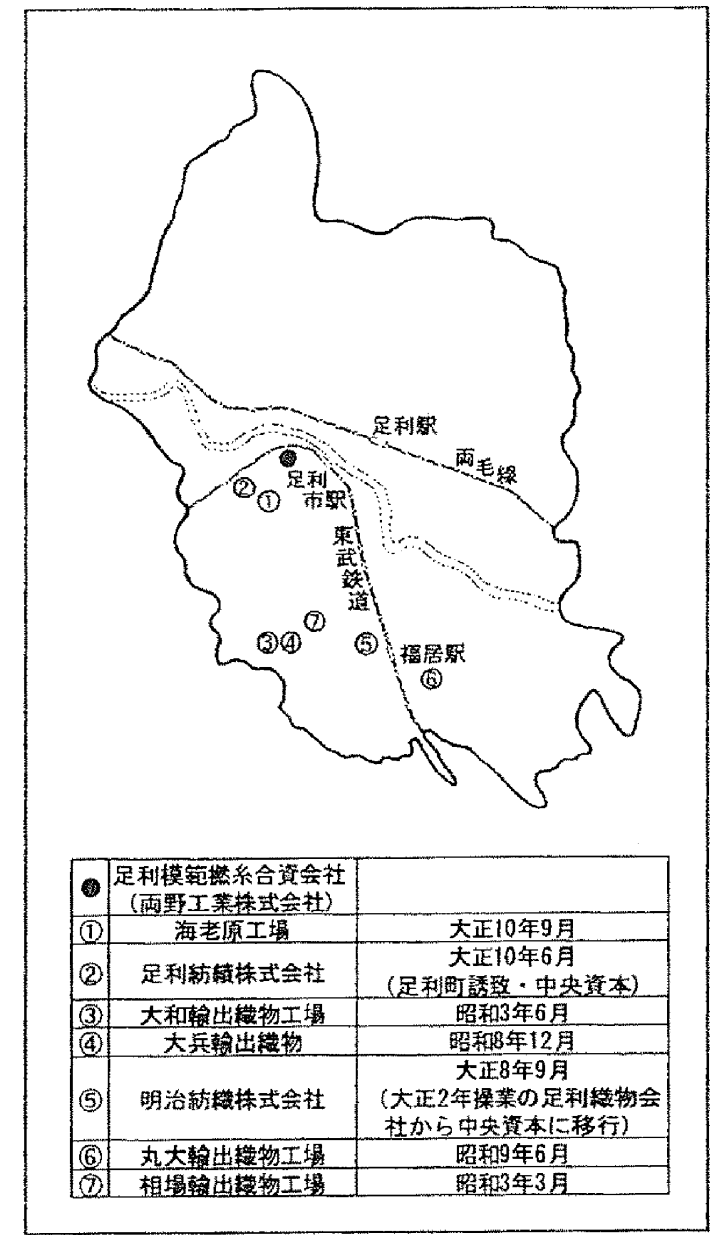

図一-12 山辺村および御底村における大让・昭和初期 設立の工場 (職工 10 人以上)

（文䓟 3、24 を基に簕者作成）

(2) 昭和初期における足利市の都市計画行政の視点は、 織物落へ向けられていた。短期間における用途地域の指 定替えは、先行する織物業の動向に対する施政の現れで あった。

明治後期から昭和初期にかけ足利織物業は工場制 機械工業化が進展し、その過程に゙おいて都市基盤整備む 進められた。特に、明治 35 年の国策による模範工場の 設立が、地場産敇の進展および都市基盤形成に大きな影 響を及ぼした。政府の当を得た政策と、工場制機械工業 化人の地域の取り程み、換言す玌ば官の意図と民の意志 により、現今の都市基盤の基㯬が形づくられたと言えよ 5 。 
謝辞

本研究に際し、足利機業の進展について貴重なご教示 を賜った杤木罧緎維工業試験場場長の岩野宏昭氏、また 資料の調査に際し多大なご助力を賜った足利市教育委員 会文化課歷史博物館建設準備室次長の市橋一郎氏、なら びに足利市都市開発部都市計画課に対し、染甚なる謝意 を表します。また、調查㧍よび論文作成にあたっては、 足利工策大学士木史研究室の学生諸君に献身的なご協力 を頂いた。ここに、記して御礼申し上げます。

補注

注 1）平安時代の院政期に編繁された東大寺の寺誌で 十章十巻加成る。『続々群書類従第十一』(国 書刊行会編 昭和 60 年 1 月 20 日第 4 版発行) によれば、『東大寺要録巻第六 封戸水田章第 八』に、東大寺の封戸として“下野国二百五十 戸 …足利郡土師鄉五十戸梁田郡梁川郷五十戸 ‥(以下略)”、さらに（下野国に対して）“調庸 布千百十端二丈五尺…(以下略)”とあり、現在 の足利市域である足利および梁田地域から、東 大寺に対して足利産織物が献納されていたこと が記されている。

注 2）第二百十六段に、最明寺入道（北条時頼）が足

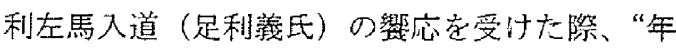
每に給はる足利の染物、心もとなく侯ふ．..(以下 略)”とあり、毎年さまざまな色に染められた足 利の織物を贈られていたことが記されている。

注 3）富岡製糸場は 1870 (明治 3）年 10 月に設立さ れ、1872（明治 5) 年 10 月に操策が開始され た。また、堺紡績所は薩摩藩により1868（明治 元）年 7 月に着工、 1870 (明治 3 ) 年 12 月に 本格的に操業を開始したが、1872（明治 5）年 5 月に政府により筫い上げられ、以降賏営模範 工場として操䍰した。应島紡績所上愛知紡績所 姑、1878（明治 11）年に内務省により官営模範 工埸としてその建設が計画され、広島紡績所は 1880（明治 13）年に着工したが 1882 (明治 15) 年 6 月に未完成のまま広岛罧に払い下げられ、 愛知紡績所は1881（明治 14）年 12 月に操業定 開始した。

注 4) 『足利織物沿革誌』によれば（参考文献 2、 pp.231-233)、日本鉄道会社の第二区線計画立 案に際し、足利の機業家であった栃木県会議員 の市川安左衛門・本村半兵衡らは、宇都宮八の 眎庁移転に賛同するこ上との引き換え儿、熊谷・ 㭊木・足利・宇都宾の迂回ルート交願い出た。

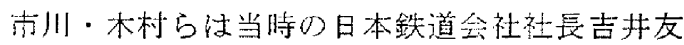

賀や内閣の諸大臣に対し運動したが、大山陸軍 大臣は、“凡そ我が國の事は大に北門に重きを置 か方可からず、兵事は貝に一呼吸の間にあり 鐵道と兵事の関係注國防上離る可からざる重大 密接のものなり一地方の便否如何に依て私する は不可なり”として反対し、結局この迁回ルー トは実現しなかった。

引用文献

（1）早稲田大学経済史学会編：『足利織物史上巻』、足利 瀻維同業会, p.22, 1960

（2）日下部高明：明治 35 年政策の模範工場について，宇 都宮地理学年報 1, p. 23,1983

（3）足利市史編纂委員会：『近代足利市史 第 5 巻 史料 編』，足利市，p.155，1979

参考文献

1）例えば、三瓶孝子:『日本機業史』，雄山閣，1961 山口和雄 :『日本産業金融史研究 織物金融篇』, 東京大学出版会, 1974

2）荒川宗四郎：『足利織物沿革誌』，雨毛實業新報社， 1902

3)早稲田大学経済史学会編：『足利織物史上・下・ 別卷』，足利瀻維同業会，1960

4）足利市史編箱委員会：『近代足利市史 第 1 巻』, 足利市， 1977

5）日下部高明：足利織物業の近代化の特徵之生産構造 の地域的展開, 地理学評論 57,1984

6)川村晃正: 明治期足利産地におりる輸出絹織物経営 一足利町木村浅七家を中心に一, 専修商学論集 59 , 1995

7) 日本地誌研究所：『日本地誌 第 5 巻』，一宮書店， pp. 131-133, 1981

8）前掲 2) に同じ。pp.15-19

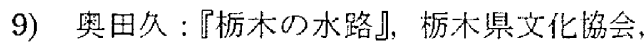
pp.310-316, 1979

10）『国史大辞典 第 7 巻』, 吉川弘文館, pp.674-675, 1986

11）早稻田大学経済史学会編:『足利織物定上卷』, 足利繊維同業会, pp.394-400, 1960

12）前揭 11）に同じ。pp. $780-781$

13）『明治 33 年杤木県勧業年報』，杤木県内務部第 四課, 明治 35 年

『明治 36 年杤木県勧業年報』，杤木柿内㹣部第 四課, 明治 38 年

『明治 38 年杤木県忤業年報』，杤木県内務部第 四課, 明治 40 年 
14)『明治 44 年杤木罚統計書』，杤木県，大正 3 年 『大正 2 年杤木県統計書』, 杤木県, 大正 5 年 『大正 $5 \cdot 6$ 年杤木罧統計書』，杤木貣，大正 8 年 『大正 $15 \cdot$ 昭和元年杤木県統計書』, 杤木県, 昭和 2 年

15）『両毛地方機織業調査報告書』，東京高等商業学 校，p.131，1901

16）日下部高明・菊地卓：『足利浪漫紀行知られざ る歴史定訪祊て』，随想舎，pp.64-65，1991

17）日下部高明：明治 35 年政策の模範工場につい 下，宇都宮地理学年報 $1, p .26,1983$

18）早稲田大学経済史学会編：『足利織物史下卷』， 足利瀻維同業会，pp.254-281，1960

19）前掲 6）に同じ。pp.98-103

20) 前掲 1）に同じ。p.272

21)『第壹回営業報告畫』，足利模範撚采合資会社， pp.1-14

22）『日本国有鉄道百年史 通史』，日本国有鉄道， pp.3-4, 1974

23）前揭 4）に同じ。pp.1026-1035

24）『東武鉄道百年史』, 東武鉄道株式会社, pp.56-61, 1998

25）前掲 4）に同じ。pp.1215-1221

26)『大正元年柘木県統計畫』, 杤木県, 大正 3 年 『昭和 4 年杤木県統計畫』, 杤禾県, 昭和 6 年 『昭和 5 年杤木県統計畫』, 杤木県, 昭和 7 年 『昭和 6 年杤木県統計書』, 栃木県, 昭和 8 年 『昭和 7 年杤木県統計書』, 杤木県, 昭和 9 年 『昭和 8 年杤木県統計書』, 杤木県, 昭和 10 年 『昭和 9 年杤木罚統計書』，杤木県，昭和 11 年

27）『明治 31 年足利郡統計㫪』，栃木県足利郡役所第一 課, 明治 34 年 『明治 32 年足利郡統計書』，栃木県足利郡役所 第一課, 明治 34 年

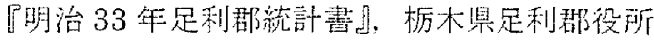
第一課, 明治 35 年

『明治 34 年足利郡統計書』, 杤木県足利郡役 所第一課, 明治 37 年

『明治 41 年足利郡統計書』，栃木県足利郡役所 第一課; 明治 44 年

『明治 44 年足利郡統計書』, 杤木県足利部役 所第一課, 大正 4 年

『大正元年足利郡統計畫』，杤木県足利郡役 所, 大正 3 年

『大正 3 年足利郡統計書』, 杤木県足利郡役 所, 大正 5 年

『大正 4 年足利郡統計書』，栃木具足利郡役 所, 大正 6 年

28）『足利市御厨支所文書 6』

29）杤木目史編寒委員会：『杤木県史通史編 8 』, pp.304-305， 1984

30）『下野新闌』昭和 3 年 3 月 15 日

31）前掲 4）に同じ。p. 1225

32）石田頼房：『日本近代都市計画史研究』，柏書堂， pp. $13-14,1992$

33）建設省都市局：『日本の都市（昭和 60 年度版）』 第一法規，pp.200-201，1985

34）足利市史編基委員会：『近代足利市史 第 4 巻 史料編』，足利市，p.228，1975

35）足利市：『議事関係緅』

36)『足利市報 第 82 号』昭和 4 年 6 月 20 日

37）前掲 34）に同じ。pp.431-437

38）『昭和 7 年足利市事務報告畵』

39）前掲 34）に同じ。pp.437-438

40）（財）都市計画協会:『近代日本都市計画年表』，p.87, 1991 